\title{
Optimization of Bioslurry-Available Plant Nutrients Using T. brownii and Acanthaceae spp. Biocatalysts
}

\author{
Bakari A. Chaka $\mathbb{D}^{1},{ }^{1}$ Aloys M. Osano $\mathbb{D}^{1},{ }^{1}$ Justin K. Maghanga $\mathbb{D}^{2},{ }^{2}$ and Martin M. Magu $\mathbb{i D}^{3}$ \\ ${ }^{1}$ Department of Mathematics and Physical Sciences, Maasai Mara University, P.O. Box 861-20500, Narok, Kenya \\ ${ }^{2}$ Department of Mathematics, Statistics and Physical Sciences, Taita Taveta University, P.O. Box 635-80300, Voi, Kenya \\ ${ }^{3}$ Department of Chemistry, Multimedia University of Kenya, P.O. Box 15653-00503, Nairobi, Kenya
}

Correspondence should be addressed to Bakari A. Chaka; bakarichaka@yahoo.com

Received 2 August 2019; Revised 25 September 2020; Accepted 24 October 2020; Published 30 November 2020

Academic Editor: Othmane Merah

Copyright (c) 2020 Bakari A. Chaka et al. This is an open access article distributed under the Creative Commons Attribution License, which permits unrestricted use, distribution, and reproduction in any medium, provided the original work is properly cited.

\begin{abstract}
The plant extracts of T. brownii and Acanthaceae spp. have been used as biocatalysts by several communities in Kenya to hasten anaerobic digestion. This study aimed at assessing the viability of these two extracts in hastening the availability of plant nutrients from bioslurry at ambient conditions. A controlled research design was followed using uncooked kitchen waste as the substrate for 28 retention days. Changes in bioslurry physicochemical properties and available plant nutrients were monitored every 7 days using wet chemistry and spectroscopic methods. The findings indicated that the two extracts significantly impacted the levels of available plant nutrients in the bioslurry compared to the control samples. T. brownii additives significantly increased the levels of lime content, total Kjeldahl nitrogen, total phosphorus, phosphoric acid, sulfur, and soluble silicic acid. On the contrary, Acanthaceae spp. additives significantly increased the levels of calcium, potassium, nitrates, total ammoniacal nitrogen, sulfates, and phosphates in the bioslurry samples. The use of these plant extracts thus reduces the time taken while increasing the concentration of available plant nutrients from bioslurry.
\end{abstract}

\section{Introduction}

Good agricultural practices trickle down to sufficient water for irrigation, good postharvest mechanisms, and storage practices as well as the use of fertilizers before and during planting seasons. Most fertilizers used are inorganic and are expensive to the majority of the farmers in Africa [1]. The primary goal of fertilizers is to supplement depleted nutrients in the surrounding of a plant. A vast portion of land in the globe has been used for tilling for many years. This has led to a gradual reduction of soil nutrients [2]. Practices such as crop rotation that help sustain soil nutrients for long are not always practicable. Fertilizer addition to a piece of land is thus exponentially increased annually. Demand for more fertilizer has, therefore, grown over time [2,3]. This has led to the diversification of fertilizer raw material leading to the adoption of organic fertilizers.
Unlike inorganic fertilizers, organic fertilizers do not have definite nutrient concentrations. The viability of organic fertilizer is dependent on many factors such as its source, decomposing period, the consortia that it has been mixed in, and other factors $[4,5]$. Albeit having lower essential plant nutrients, this type of fertilizer is preferred due to its quick biodegradability nature [6]. Several inorganic fertilizers leach into the soil deeply due to high concentration and solubility finding their way into water systems. The long-lasting fate of this phenomenon is water pollution. Other inorganic fertilizers used volatilize quickly leading to massive loss of fertilizer to the target site and air pollution [7]. In organic fertilizer, the soluble and volatile nutrients are embedded in a myriad of organic compounds which hold them together [8]. This reduces the chances of both water and air pollution.

Organic fertilizer is cheap due to the availability of agricultural residues and animal manure in rural farms. The 
preparation of organic manure is also quite easy and occasionally involves mixing consortia of agricultural residues and/or animal manure and allowing for decomposition to occur. Organic fertilizer should, however, be prevented from direct sunlight which can trigger some side reactions [9]. Plants grown by organic manure are preferred since the fertilizer also has antimicrobial activities which kill pests without leaving behind toxic chemicals [10]. Anaerobic digestion of agricultural residues or animal manure using a biogas digester is an excellent method of preparing organic fertilizer. The fertilizer is termed as bioslurry.

Biogas slurry, or bioslurry, is obtained after biogas substrate has completed the required retention time in a biogas digester [11]. The optimum bioslurry tapping point from a biogas digester should be at the onset of gas production [12]. The time taken is known as the solid retention time and can be defined as the period when more than half of the total solids have been converted to volatile solids [13]. Intrinsically, the solid retention time of agricultural residues is long due to the strong nature of glycosidic and amide bonds that have to be broken [14]. More energy is required to break these bonds to free the nutrients in a form that can easily be taken by plant roots [15].

Several traditional African communities used various salts and plant extracts to hasten the breakdown of biomass [15]. The ancient Aandia community found that on the western slopes of Mt Kenya, T. brownii leave extracts were used to hasten saccharification of wheat bran (cellulose) during the preparation of their traditional alcohol. The Maasai community of Kenya has continuously enjoyed hastening the fermentation process during the preparation of their native alcohol using Acanthaceae spp. bark extracts. The aim of this work was to investigate whether the use of these two biocatalysts in biogas systems could optimize the availability of plant nutrients in the bioslurry. The use of biocatalysts in the optimization of available plant nutrients is quite cheap and easy to use.

\section{Materials and Methods}

2.1. Design of Experiment. Three biodigesters of capacity 40.0 liters operated at mesophilic temperature regime were used to monitor the levels of available nutrients in bioslurry. The digesters were all maintained in batch mode. A 30-day retention period was used. Biogas substrate comprising $67 \%$ by weight uncooked kitchen waste and the rest inoculum (cow and goat dung in ratio $1: 1$ ) was used. The substrate mixture above (kitchen waste and inoculum) was soaked using distilled water (10\% water) for 24 hours prior to loading into the biodigesters. Two of the digesters were dosed with $5 \% \mathrm{v} / \mathrm{v}$ additive (T. brownii and Acanthaceae spp. extracts) while the third biodigester was the control setup. The number of replicates was limited by the study budget. Prior to loading, the kitchen waste substrate was characterized by anaerobic digester parameters. The two additives were also characterized for possible functional groups and absorption peaks by FT-IR (Shimadzu-119; Tokyo, Japan)) and UV-VIS (Jenway-6850; Staffordshire, UK), respectively.
Characterizing the bioslurry substrate and monitoring the levels of available nutrients were done at Maasai Mara University, Kenya. Volatile organic salts/total anorganic carbon (VOS/TAC Pronova 2000; Berlin, Germany) analysis tests and quantitative UV-VIS analysis for levels of free ligands in the bioslurry across the retention period were done at Taita Taveta University, Kenya. UV-VIS analysis for levels of nitrates, sulfates, and phosphates on retention day 28 was done at Vaal University, South Africa.

\section{Materials}

3.1. Biogas Substrate Used. The kitchen waste used was characterized to have an average $\mathrm{pH}$ of $6.300 \pm 0.001$ and an electrical conductivity value of $1.293 \pm 0.002 \mu \mathrm{s}$. The total solids content was $11.1566 \pm 0.668 \mathrm{~g} / \mathrm{L}$ against a volatile solid content of $11.283 \pm 0.008 \mathrm{~g} / \mathrm{L}$ implying that most of the solids were actually volatile and not fixed solids. This showed that the substrate had a lot of organic matter. The total suspended solids were $7.253 \pm 0.672 \mathrm{~g} / \mathrm{L}$ while the total dissolved solids were $3.904 \pm 0.003 \mathrm{~g} / \mathrm{L}$. The average values of alkalinity and volatile fatty acid levels were $0.900 \pm 0.132 \mathrm{mg} / \mathrm{L}$ and $14.580 \pm 0.811 \mathrm{mg} / \mathrm{L}$. The average VOS/TAC value was $1.240 \pm 0.020$. The elemental composition values were dissolved oxygen of $8.500 \pm 0.476 \%$, organic carbon of $21.600 \pm 2.400 \mathrm{~g} / \mathrm{L}$, nitrogen of $3.067 \pm 0.540 \mathrm{~g} / \mathrm{L}$, and phosphorus content of $0.780 \pm 0.020 \mathrm{~g} / \mathrm{L}$.

\section{Methods}

\subsection{Extraction and Characterization of Biocatalysts}

4.1.1. Extraction. T. brownii leaves and Acanthaceae spp. barks were collected from Kirinyaga County, Kenya $\left(0.6591^{\circ} \mathrm{S}, 37.3827^{\circ} \mathrm{E}\right)$, and Narok county, Kenya $\left(1.1041^{\circ} \mathrm{S}\right.$, $\left.36.0893^{\circ} \mathrm{E}\right)$, respectively.

T. brownii fresh leaves were squeezed, and $5 \mathrm{ml}$ of the resulting crude extracts was soaked in distilled water to make a $100 \mathrm{ml}$ solution. The solution was left to macerate completely for 24 hours at room temperature away from direct light. The mixture was then serially filtered using the Whatman no. 42 filter papers and the resulting solution was preserved.

To prepare Acanthaceae spp. extracts, the barks of these samples were ground to a fine powder. $5 \mathrm{~g}$ of these powders was soaked in $100 \mathrm{ml}$ distilled water. The mixture was then left to macerate and filtered as was the case with T. brownii.

The two extracts were then subjected to functional group by IR analysis (Shimadzu-119) and absorption peaks analysis by UV-VIS (Jenway-6850).

\subsubsection{Bioslurry Analysis for Available Plant Nutrients}

(1) $\mathrm{pH}$ and Dissolved Oxygen. $\mathrm{pH}$ and dissolved oxygen were measured by the use of a $\mathrm{pH}$ meter (Hanna G-114; Woonsocket, USA) and oxygen meter (GPro-500; California, USA). 
(2) Total Solids. $10.000 \mathrm{~g}$ of the sample was weighed, $M_{1}$ using an analytical balance, and then placed in an oven conditioned at $105^{\circ} \mathrm{C}$ for 6 hours before removing, cooling (in a desiccator), and reweighing. The new mass was recorded as $M_{2}$ :

$$
\% \mathrm{TS}=\frac{M_{2}}{M_{1}} \times 100 \%
$$

(3) Nitrogen Determination by Kjeldahl Method. This method was according to [16]. Total Kjeldahl nitrogen analysis was carried out according to the Kjeldahl standard method. The samples were digested in potassium sulfate, anhydrous copper sulfate, and sulfuric acid. The digestate was then distilled in $20 \%$ hydrochloric acid. The distillate was titrated with standard sodium hydroxide solution and the concentration of nitrogen in the sample calculated.

(4) Organic Carbon Determination by Walkley-Black Method. Organic carbon in the samples was determined by the Walkley-Black method [17].

A fixed mass of the sample was treated with a potassium dichromate solution followed by concentrated sulfuric acid. The mixture was swirled and left to digest for 16-18 hours in a fume hood. The resulting solution was diluted and backtitrated with standard ferrous ammonium sulfate solution. A blank analysis was also done:

$$
\operatorname{Organic} \operatorname{carbon}(\%)=\left(\frac{(B-S) \times 0.0006}{m}\right) \times 100,
$$

where $B$ is the volume of ferrous solution used in the blank titration, $S$ is the volume of ferrous solution used in the sample titration, and $m$ is the mass of the sample in grams used in the analysis. No correction factor was applied to the OC content calculation.

(5) Total Phosphorus Analysis. A sample was dissolved in water and filtered. The filtrate was reacted with the magnesium sulfate solution before filtering again. The solution was gradually precipitated with standard ammonia solution while stirring. The precipitate formed was quantitatively transferred to a preweighed filter paper. The filter paper and its contents were washed with water and 95\% ethanol before spreading on a watch glass for 8 hours and drying in an oven at $100^{\circ} \mathrm{C}$ for 1 hour. The mixture was thereafter cooled and the mass of residue was obtained.

(6) Nitrates. Nitrate standards were prepared by dissolving $8.0 \mathrm{~g}$ of salicyclic acid in $100 \mathrm{ml}$ of $1 \mathrm{M} \mathrm{H}_{2} \mathrm{SO}_{4}$ acid then swirling to fully dissolve. $10 \mathrm{ml}$ of this solution was added to $90 \mathrm{ml}$ of the aliquot sample solution. Acidification using $1 \mathrm{M}$ $\mathrm{HCl}$ was done to minimize interference by other ligands. Absorbance was checked in the range of $270-320 \mathrm{~nm}$.

(7) Sulfates. For standard preparation, $10 \mathrm{~g}$ of $\mathrm{NaCl}$ and $10 \mathrm{ml}$ of conc. $\mathrm{HCl}$ acid were added to $40 \mathrm{ml}$ of glycerol solution. A yellowish color was formed. $5 \mathrm{ml}$ of this solution was added to $45 \mathrm{ml}$ of analyte solution and the absorbance was read at $410-430 \mathrm{~nm}$.

(8) Phosphates. A conditioning reagent was made by dissolving $1.7081 \mathrm{~g}$ of ammonium molybdate and ascorbic acid ( $5.82 \mathrm{~g} / 300 \mathrm{ml}$ distilled water) in $150 \mathrm{ml}$ warm water. The solution was cooled before diluting to $250 \mathrm{ml}$. $0.125 \mathrm{~g}$ of hydrazine sulfate in $100 \mathrm{ml}$ distilled water was added.

Analyte samples were diluted by a factor of 10 , and the conditioning reagent was added before measuring the absorbance at $830-860 \mathrm{~nm}$ against those of the blank and standards.

(9) Potassium. This method is according to [18]. $10 \mathrm{ml}$ of ammonium acetate in acetic acid solution was added to $40 \mathrm{ml}$ of sample solution diluted 40 folds. The ammonium acetate/acetic acid solution was prepared by dissolving $15 \mathrm{~g}$ of the salt in $50 \mathrm{ml}$ acetic acid. Absorbance was then read at 260-280 $\mathrm{nm}$.

(10) Loss On Ignition (LOI). $1.0 \mathrm{~g}$ of sample was put into a preweighed crucible and subjected to high temperature $\left(>540^{\circ} \mathrm{C}\right)$ in an oven for 1 hour, cooled in a desiccator, and then reweighed.

(11) Biofertilizer Alkalinity (Lime Content). $1.0 \mathrm{~g}$ of the sample was dissolved in $100 \mathrm{ml}$ of distilled water in a beaker and thoroughly stirred. The $\mathrm{pH}$ of this mixture was then taken, and $1 \mathrm{M} \mathrm{HCl}$ acid solution was added dropwise to the mixture (with $\mathrm{pH}$ probe inserted) until $\mathrm{pH} 4.3$ is attained. The number of drops used was then quantified.

(12) Total Ammoniacal Nitrogen (TAN) by Formaldehyde Method. The method is according to $[19,20]$. A sample of the bioslurry was digested in hydrochloric acid to completely effervescence. Aluminum chloride and indicator solutions were, thereafter, added before filtering. The potassium hydroxide solution was added to the filtrate solution gradually until the color of the mixture changed. The mixture was then reacted with standard hydrochloric acid and formaldehyde solution before standardizing with sodium hydroxide solution.

For the blank determination, $100 \mathrm{ml}$ of $1 \mathrm{M} \mathrm{HCl}$ acid and $10.0 \mathrm{ml}$ of formaldehyde acid were used:

$$
\% \mathrm{NH}_{3}=\left(V_{S}-V_{B}\right) \times C \times f \times \frac{V_{1}}{V_{2}} \times \frac{14.007}{W} \times \frac{100}{1000},
$$

where $V_{S}$ is the sample volume, $V_{B}$ is the blank volume, $c$ is the concentration of titrant in mol/liter, $f$ is the ammonia factor, $V_{1}$ is the volume of the sample solution, $V_{2}$ is the volume of sample solution transferred after filtration, and $W$ is the weight of sample in grams.

(13) Total Phosphoric Acid (TPA) by Quinoline Gravimetric Analysis. The method is according to [19,21]. A sample of the analyte was digested with sulfuric acid, potassium sulfate, and hydrated copper sulfate. Distilled water was added to the mixture after white fumes had cleared the flask. A portion of 
this mixture $\left(V_{2}\right)$ was mixed with concentrated sulfuric acid and quimociac solution (prepared using quinoline and sodium molybdate). The mixture was filtered and the residue was ashed onto a preweighed filter paper:

$$
\left(T-\mathrm{P}_{2} \mathrm{O}_{5}\right) \%=A \times 32.07 \times \frac{100}{1000} \times \frac{V_{1}}{V_{2}} \times \frac{1}{W},
$$

where $A$ is the mass of precipitate and $W$ is the weight of the sample in grams.

(14) Soluble Silicic Acid by Perchloric Acid Method. The method is according to $[19,21] .1 .0 \mathrm{~g}$ of sample was added onto $50.0 \mathrm{ml}$ of conc. $\mathrm{HCl}$ acid to allow for effervescence before filtering. The solution obtained is $V_{1} .30 .0 \mathrm{ml}$ of the above solution $\left(V_{2}\right)$ was added to conc. perchloric acid and heated. After white fumes are observed, the heating flask was covered to prevent fume loss and heating continued for a further 15-20 minutes. The mixture was then cooled for 30 minutes before adding $50 \mathrm{ml} 1 \mathrm{M} \mathrm{HCl}$ acid and reheating (while still covered) at $70-80^{\circ} \mathrm{C}$. The mixture was then filtered using a preweighed filter paper and washed thoroughly using $1 \mathrm{M} \mathrm{HCl}$ acid and hot water solution before drying for 1 hour at $120^{\circ} \mathrm{C}$. The filter paper with its contents was then ignited at high temperature $\left(>1200^{\circ} \mathrm{C}\right)$ using a preweighed crucible, and the mass of residue was taken after cooling:

$$
\left(S-\mathrm{SiO}_{2}\right) \%=A \times \frac{V_{1}}{V_{2}} \times \frac{1}{W} \times 100,
$$

where $A$ is the mass of precipitate.

(15) Total Sulfur Content by Barium Chloride Gravimetric Method. The method is according to $[20,22] .1 .0 \mathrm{~g}$ of sample $(W)$ was added to $50.0 \mathrm{ml}$ of potassium hydroxide/ethanol mixture as $V_{1}$. The mixture was then heated to boil. Thereafter, $250 \mathrm{ml}$ of distilled water was added to the mixture $\left(V_{2}\right)$ and filtered. $50.0 \mathrm{ml}$ of water and $5.0 \mathrm{ml}$ of hydrogen peroxide were added to the filtrate solution before reheating for 15-20 minutes. After cooling, 2 drops of phenolphthalein indicator were added, and then $1 \mathrm{M} \mathrm{HCl}$ acid was added until the color changed again. $50.0 \mathrm{ml}$ of $1 \mathrm{M} \mathrm{HCl}$ acid solution was then added and the mixture was boiled for 5 minutes. $6.0 \mathrm{ml}$ of saturated barium chloride solution was added and the mixture was filtered using a preweighed filter paper. The contents were then ignited at above $800^{\circ} \mathrm{C}$ using a preweighed crucible and mass change was recorded as $A$ :

$$
\text { T.Sulfur } \%=(A \times 0.343) \times W \times \frac{V_{2}}{V_{1}} \times 100 \text {. }
$$

4.2. Data Analysis. Data collected was reported as a mean \pm standard deviation. 14 degrees of freedom were used. The confidence level used was 95\%. Statistical analysis was done using Ms Excel and OriginLab (version 6.5) software.

\section{Results and Discussion}

5.1. Functional Group Peaks of the Additives. The FT-IR profiles of both extracts were similar toward the blue end but differed in functional group peaks and intensity toward the right of their FT-IR spectra. Carboxylic- $\mathrm{OH}_{\text {stretch }} \mathrm{sp}^{3} \mathrm{C}-\mathrm{H}$, and

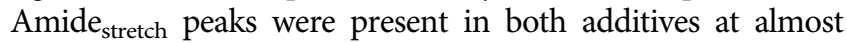
equal intensity. These peaks indicated the presence of weak carboxylic acids present in the extracts [23]. The carbonyl peak at $1680 \mathrm{~cm}^{-1}$ in $T$. brownii extracts was more pronounced compared to that in Acanthaceae spp. In contrast, the $\mathrm{C}-\mathrm{O}_{\text {stretch }}$ peak at $1035 \mathrm{~cm}^{-1}$ in Acanthaceae spp. was more pronounced while T. brownii extract had more fingerprint peaks, key among them being trans $=\mathrm{C}-\mathrm{H}_{\text {bend }}$ and $=\mathrm{C}-\mathrm{H}_{\text {bend }}$ peaks. Of more interest was the $\mathrm{C}-\mathrm{X}_{\text {bend }}$ peak at $560 \mathrm{~cm}^{-1}$ in the $T$. brownii extract. Increased diversity of organic compounds enhances reactivity [24]. The collated FT-IR spectra of the two additives are as shown in Figure 1.

5.2. Absorption Peaks of Additives. Plant extracts are known to have several absorption peaks arising from various organic compounds [25]. The UV-VIS spectra of these additives are in Figure 2.

The extracts' spectra had more peaks before $300 \mathrm{~nm}$ indicating the presence of absorption peaks. T. brownii had peaks at $215 \mathrm{~nm}$ and $240 \mathrm{~nm}$ illustrating more absorption as a result of $\pi-\pi^{*}$ transition [26]. Characteristics peaks at $300 \mathrm{~nm}$ and $840 \mathrm{~nm}$ indicated the presence of isolated carbonyls, nitrates, and phosphates in the extracts $[27,28]$. $\lambda_{\max }$ at $460 \mathrm{~nm}$ indicated trace presence of carotenoids while $\lambda_{\max }$ at $595 \mathrm{~nm}$ indicated the presence of a more conjugated compound (e.g., a blue dye). An increase in the number of absorption peaks leads to a shift of electron density which destabilizes organic molecules making them prone to electrophilic and nucleophilic attacks [29]. This effect leads to hydrolysis of the biomass which frees more nutrients for plant uptake.

\section{Bioslurry Available Fertilizer Analysis}

The elemental composition of bioslurry at different retention periods is crucial in defining its potential as an organic fertilizer [30]. The availability of these essential nutrients for reach by plant roots is also important [31]. Several bioslurry parameters and elemental composition of elements and their ions were done at different retention periods and summarized hereinafter.

6.1. Bioslurry $p H$. The $\mathrm{pH}$ value of fertilizer is quite important since different plants produce optimally in different soil $\mathrm{pH}$ values $[32,33]$. Various soil microorganisms are also affected by $\mathrm{pH}$ changes. Table 1 illustrates the changes in bioslurry $\mathrm{pH}$ over the retention period used.

Changes in $\mathrm{pH}$ values in anaerobic systems are largely dictated by the type of biomass present and inoculum used [34]. Kitchen waste residues had high volatile fatty acids and were thus acidic at the beginning of anaerobic digestion. The initial stages of anaerobic digestion (hydrolysis, acidogenesis, and acetogenesis) are controlled by acidic enzymes and end up giving acidic products [35]. The $\mathrm{pH}$ of bioslurry was thus quite acidic after day 7 . Retention day 14 had a neutral $\mathrm{pH}$ due to methanogenesis which occurs in neutral 


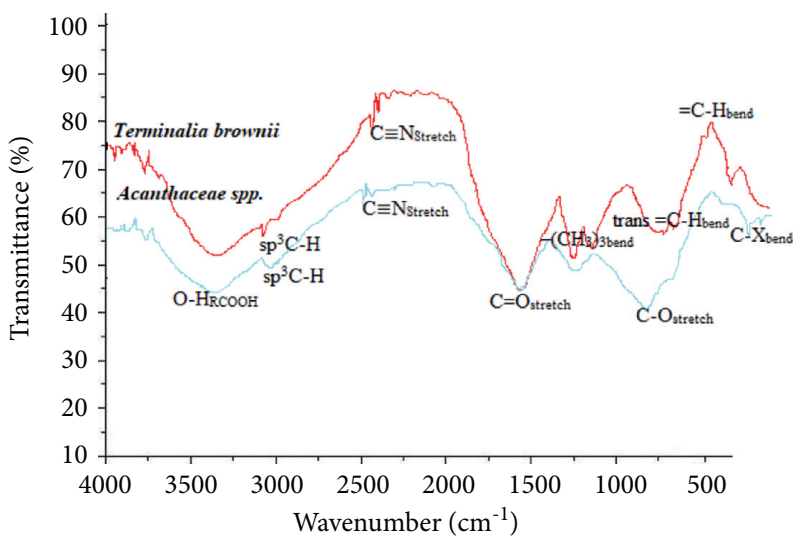

Figure 1: FT-IR spectra of T. brownii (red) and Acanthaceae spp. (blue) extracts. Though relatively similar, T. brownii extracts showed more functional group peaks.

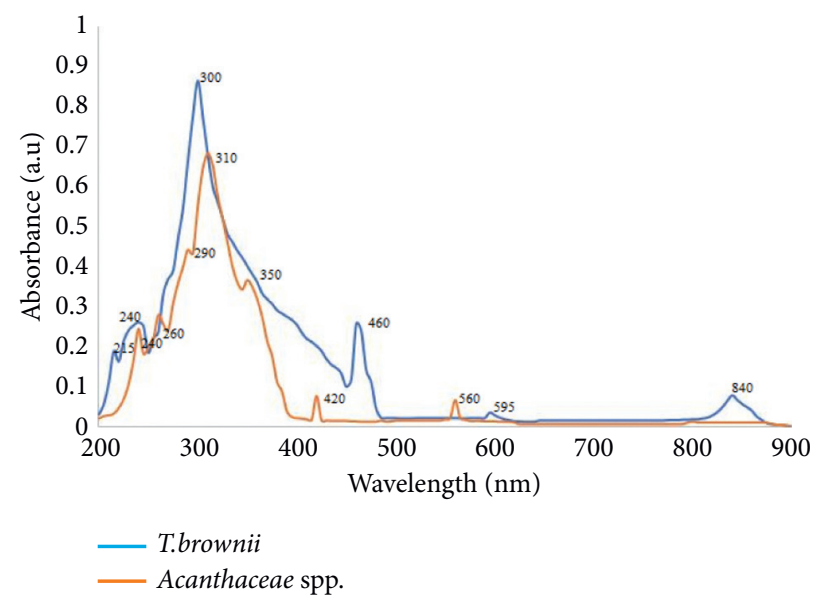

Figure 2: UV-VIS analysis of T. brownii and Acanthaceae spp. extracts. The spectra show more peaks toward the blue end of the spectra.

TABLE 1: changes in $\mathrm{pH}$ value of bioslurry.

\begin{tabular}{lcccrr}
\hline Samples & \multicolumn{3}{c}{ Sample pH } \\
& Day 1 & Day 7 & Day 14 & Day 21 & $5.880 \pm 0.010$ \\
Control & $6.300 \pm 0.001$ & $5.850 \pm 0.001$ & $6.950 \pm 0.022$ & $6.230 \pm 0.003$ & $5.860 \pm 0.003$ \\
T. brownii & $6.070 \pm 0.001$ & $5.770 \pm 0.017$ & $7.120 \pm 0.022$ & $6.230 \pm 0.017$ & $5.910 \pm 0.010$ \\
Acanthaceae spp. & $6.750 \pm 0.017$ & $5.830 \pm 0.010$ & $6.850 \pm 0.017$ & $6.210 \pm 0.017$ & 5 \\
\hline
\end{tabular}

$\mathrm{pH}$ [36]. Sample with T. brownii extracts had the highest $\mathrm{pH}$ value of $7.120 \pm 0.022$. This implies that this was the best time to collect its bioslurry. Thereafter, the organic load necessary for methanogenesis declined (since the digesters were in batch mode), and bacteria present started hydrolyzing the unreacted biomass leading to previous anaerobic digestion processes and a gradual decrease in $\mathrm{pH}$ [37]. The additives also increased biogas yields from the AD systems. The order of biogas output was T. brownii (1586.14 ml/g VS), Acanthaceae spp. (1321.96 ml/g VS), and control $(744.48 \mathrm{ml} / \mathrm{g}$ VS). The methane levels were in the order of $T$. brownii $(43.475 \pm 0.9215 \%)$, control sample $(41.750 \pm 1.4012 \%)$, and Acanthaceae spp. (39.275 $\pm 0.2629 \%)$. After 28 -day retention time, the Acanthaceae spp. sample had more $\mathrm{pH}$ value than the other samples $(5.910 \pm 0.010)$. This was the most suitable sample for the growth of most plants [38]. There was, however, no significant variation in $\mathrm{pH}$ as a result of the use of the two additives at a $95 \%$ confidence level $(n=14)$.

6.2. Bioslurry Electrical Conductivity (EC). Variation in EC values as a function of using the two additives is important in assessing the viability of the additives. Table 2 summarizes the changes in EC values over the retention period.

The EC values declined after retention day 7 as volatile acids in the organic load increased. Around the 14th retention day, there was less organic matrix in the ions present which were easily detected leading to higher EC values. An ultimate range of $4.520 \pm 0.003$ (Control sample) to $5.250 \pm 0.027 \mu \mathrm{S}$ (Acanthaceae spp.) was attained which is 
TABLE 2: Variation in bioslurry EC over a 30-day retention period.

\begin{tabular}{lcccrr}
\hline Samples & & \multicolumn{3}{c}{ Sample EC $(\mu \mathrm{S})$} \\
& Day 1 & Day 7 & Day 14 & Day 21 & $4.520 \pm 0.003$ \\
\hline Control & $4.040 \pm 0.010$ & $3.810 \pm 0.003$ & $5.350 \pm 0.003$ & $4.990 \pm 0.021$ & \\
T. brownii & $4.420 \pm 0.010$ & $3.750 \pm 0.017$ & $5.570 \pm 0.003$ & $5.490 \pm 0.003$ & $4.770 \pm 0.021$ \\
Acanthaceae spp. & $4.340 \pm 0.003$ & $4.410 \pm 0.003$ & $5.000 \pm 0.020$ & $6.040 \pm 0.017$ & $5.250 \pm 0.027$ \\
\hline
\end{tabular}

optimal for solubility of plant nutrients and their uptake by roots [39]. Electrical conductivity values in slurry depict the presence of soluble ions for plant roots to uptake. High EC values imply that the bioslurry is quite soluble and can thus require less water during application to plants.

6.3. Bioslurry Total Solid (TS) and Loss on Ignition (LOI). The content of total solids in a fertilizer sample is crucial in determining its primary mode of application. Table 3 summarizes the TS and LOI variation in the bioslurry over the retention period.

The TS of the samples decreased linearly over the retention period to about one-third of the initial value by the 28th day. Hydrolysis of kitchen waste biomass in the sample with $T$. brownii extract was accelerated by a large margin as evidenced by the reduction in TS within the first week by about half $(12.320 \pm 0.317 \mathrm{~g} / \mathrm{L}$ to $5.129 \pm 0.022 \mathrm{~g} / \mathrm{L})$. The LOI values in $T$. brownii sample were also quickly reduced. The bioslurry from this extract thus had low TS and LOI values making it suitable as a top dress or for foliar application. The TS and LOI values of samples with the Acanthaceae spp. extract were quite high right from the onset indicating more particulate levels in this sample. This bioslurry is, therefore, not appropriate for aerial application.

Fertilizer samples with high total solids content require more water if they are to be applied as top-dressing fertilizer [40]. On the contrary, low TS content implies that the fertilizer can easily be applied by top-dressing. High LOI values imply that the bioslurry fertilizer should not be on the soil surface to minimize evaporation. High LOI bioslurry is volatile, and most of it does not end in the target location when applied as a top-dressing fertilizer. Such fertilizer samples require to be planted together with the plant or injected into the soil. The eventual TS and LOI values in all digester samples were significantly different at a 95\% confidence level $(n=14)$. This implies that the two types of additives should not be applied in a similar method for optimal absorption by plants.

6.4. Bioslurry Alkalinity (Lime Content). The alkalinity of bioslurry implies its ability to buffer acidic soil. Many plants perform optimally in neutral and slightly basic soil [38, 41]. Table 4 illustrates the variation in alkalinity values in the bioslurry samples.

The control sample had the highest alkalinity level at the onset which drastically reduced after 7 days of the retention period. This can be attributed to precursor reactions that lead to the formation of volatile acids such as acetic, propanoic, and butyric acid [42]. The control sample had thus very little buffering capacity which has direct effects on the bioslurry quality. While the alkalinity levels of Acanthaceae spp. samples had little variations, those of the T. brownii sample largely fluctuated. T. brownii sample had the highest alkalinity level of $0.558 \pm 0.075 \mathrm{~g} / \mathrm{L}$ after 28 days. This value was significantly different from the rest at a $95 \%$ confidence level $(n=14)$. Bioslurry alkalinity is primarily contributed to its lime content and has previously been used as an indicator of lime levels [43]. High alkali levels are desired for any bioslurry as the fertilizer can work well in acidic soils.

6.5. Bioslurry Oxygen, Calcium, Carbon, and Potassium Levels. The elemental composition of bioslurry is quite useful as these elements are the required plant nutrients. Elucidation of whether an element is a micro- or macronutrient varies with different types of plants as well as their growth stage [44]. Table 5 summarizes the abundance and variation of these elements in the bioslurry over the retention period.

From the substrate analysis, volatile solids and total suspended solids declined over retention time. Similarly, oxygen and carbon content in the bioslurry of all three samples decreased linearly. The dissolved oxygen at the onset of digestion is gradually converted into other byproducts by anaerobic archaea present in the slurry [45]. Similarly, carbon is the main element in biomass for the production of methane. Carbon present as carbohydrates, lipids, or proteins is sequentially converted to low weight acids (acetic, propionic, and butyric) and then to acetic acid and hydrogen and ultimately to methane, carbon dioxide, and other by-products [46]. The oxygen and carbon levels at retention day 28 are thus the lowest in the series. The sample with $T$. brownii extracts had the largest disparity in carbon content after the 28-day retention period due to massive biogas conversion by this sample. This sample had lower bioslurry viability as far as oxygen and carbon are concerned. Wang et al. [47] showed that the use of bioslurry from poultry dung had almost similar carbon content with mineral fertilizer. Available carbon from the bioslurries above was higher than that obtained when using slurry with pure animal manure origin $(1.3 \%)$ [48].

Unlike oxygen and carbon, calcium and potassium content increased over time. As the organic matrix in the biomass was being converted into biogas, the inorganic ions availability increased as these ions were continuously being freed. This is also justified in the increment of the total dissolved solids (as seen above). Acanthaceae spp. sample 
TABLE 3: Variation of TS and LOI levels in the bioslurry over the retention period.

\begin{tabular}{|c|c|c|c|c|c|c|}
\hline \multirow{2}{*}{ Samples } & \multirow{2}{*}{ Parameter } & \multicolumn{5}{|c|}{ Sample days } \\
\hline & & Day 1 & Day 7 & Day 14 & Day 21 & Day 28 \\
\hline \multirow{2}{*}{ Control } & $\mathrm{TS}(\mathrm{g} / \mathrm{L})$ & $11.156 \pm 0.668$ & $8.492 \pm 0.313$ & $5.663 \pm 0.451$ & $5.198 \pm 0.333$ & $4.653 \pm 0.616$ \\
\hline & LOI $(\mathrm{g} / \mathrm{L})$ & $11.283 \pm 0.787$ & $7.956 \pm 0.881$ & $5.106 \pm 0.661$ & $4.508 \pm 0.791$ & $4.312 \pm 0.669$ \\
\hline \multirow{2}{*}{ T. brownii } & $\mathrm{TS}(\mathrm{g} / \mathrm{L})$ & $12.320 \pm 0.317$ & $5.129 \pm 0.022$ & $4.751 \pm 0.394$ & $3.985 \pm 0.612$ & $3.664 \pm 0.217$ \\
\hline & LOI $(\mathrm{g} / \mathrm{L})$ & $12.294 \pm 0.991$ & $4.597 \pm 1.013$ & $4.313 \pm 0.788$ & $3.845 \pm 0.799$ & $3.552 \pm 0.813$ \\
\hline \multirow{2}{*}{ Acanthaceae spp. } & TS $(\mathrm{g} / \mathrm{L})$ & $12.361 \pm 3.056$ & $8.786 \pm 0.527$ & $7.026 \pm 0.821$ & $6.522 \pm 0.142$ & $6.435 \pm 0.899$ \\
\hline & LOI $(\mathrm{g} / \mathrm{L})$ & $8.737 \pm 1.012$ & $8.634 \pm 0.129$ & $6.666 \pm 0.189$ & $5.182 \pm 0.623$ & $4.892 \pm 0.677$ \\
\hline
\end{tabular}

TABle 4: Variation in lime content of the bioslurry over the retention period.

\begin{tabular}{lcccrr}
\hline \multirow{2}{*}{ Samples } & \multicolumn{4}{c}{ Bioslurry alkalinity (lime content) $(\mathrm{g} / \mathrm{L})$} \\
& Day 1 & Day 7 & Day 14 & Day 21 & Day 28 \\
\hline Control $(\mathrm{mg} / \mathrm{L})$ & $0.900 \pm 0.132$ & $0.298 \pm 0.001$ & $0.336 \pm 0.000$ & $0.342 \pm 0.012$ & $0.422 \pm 0.068$ \\
T. brownii $(\mathrm{mg} / \mathrm{L})$ & $0.517 \pm 0.029$ & $0.412 \pm 0.228$ & $0.384 \pm 0.089$ & $0.486 \pm 0.098$ & $0.558 \pm 0.075$ \\
Acanthaceae spp. $(\mathrm{mg} / \mathrm{L})$ & $0.467 \pm 0.057$ & $0.384 \pm 0.089$ & $0.412 \pm 0.128$ & $0.422 \pm 0.068$ & $0.480 \pm 0.000$ \\
\hline
\end{tabular}

TABLE 5: Variation in oxygen, carbon, calcium, and potassium in bioslurry.

\begin{tabular}{|c|c|c|c|c|c|c|}
\hline \multirow{2}{*}{ Samples } & \multirow{2}{*}{ Parameters } & \multicolumn{5}{|c|}{ Sample days } \\
\hline & & Day 1 & Day 7 & Day 14 & Day 21 & Day 28 \\
\hline \multirow{4}{*}{ Control } & Oxygen (\%) & $9.200 \pm 0.017$ & $8.300 \pm 0.013$ & $8.100 \pm 0.013$ & $8.100 \pm 0.100$ & $7.800 \pm 0.013$ \\
\hline & Carbon (g/L) & $21.060 \pm 0.000$ & $20.600 \pm 0.451$ & $19.890 \pm 0.313$ & $18.990 \pm 0.245$ & $18.600 \pm 2.400$ \\
\hline & Calcium (g/L) & $3.700 \pm 0.007$ & $4.000 \pm 0.000$ & $5.300 \pm 0.013$ & $5.800 \pm 0.002$ & $6.000 \pm 0.000$ \\
\hline & Potassium (ppm) & $42.680 \pm 0.000$ & $42.820 \pm 0.000$ & $43.920 \pm 0.000$ & $44.470 \pm 0.000$ & $44.610 \pm 0.000$ \\
\hline \multirow{4}{*}{ T. brownii } & Oxygen (\%) & $9.400 \pm 0.100$ & $8.600 \pm 0.023$ & $8.000 \pm 0.013$ & $7.500 \pm 0.013$ & $7.400 \pm 0.100$ \\
\hline & Carbon $(\mathrm{g} / \mathrm{L})$ & $22.330 \pm 0.215$ & $20.870 \pm 0.000$ & $19.880 \pm 0.837$ & $18.440 \pm 0.612$ & $17.80 \pm 0.698$ \\
\hline & Calcium $(\mathrm{g} / \mathrm{L})$ & $2.000 \pm 0.010$ & $5.300 \pm 0.002$ & $8.700 \pm 0.000$ & $11.000 \pm 0.001$ & $11.070 \pm 0.001$ \\
\hline & Potassium (ppm) & $44.060 \pm 0.000$ & $44.880 \pm 0.000$ & $45.290 \pm 0.000$ & $46.260 \pm 0.000$ & $46.540 \pm 0.000$ \\
\hline \multirow{4}{*}{ Acanthaceae spp. } & Oxygen (\%) & $9.300 \pm 0.013$ & $9.200 \pm 0.017$ & $8.700 \pm 0.042$ & $7.800 \pm 0.013$ & $7.520 \pm 0.100$ \\
\hline & Carbon (g/L) & $21.980 \pm 0.413$ & $21.440 \pm 0.691$ & $20.250 \pm 0.000$ & $20.06 \pm 0.521$ & $18.00 \pm 2.400$ \\
\hline & Calcium (g/L) & $6.700 \pm 0.001$ & $8.700 \pm 0.002$ & $10.000 \pm 0.010$ & $11.000 \pm 0.010$ & $11.700 \pm 0.013$ \\
\hline & Potassium (ppm) & $44.400 \pm 0.000$ & $45.020 \pm 0.000$ & $45.290 \pm 0.000$ & $46.540 \pm 0.000$ & $46.560 \pm 0.000$ \\
\hline
\end{tabular}

which had the highest total solids and total dissolved solids had the highest calcium and potassium levels.

6.6. Bioslurry Nitrogen Content. Being the most vital nutrient for plant growth and optimal production [41], elucidation of nitrogen levels in their various forms in bioslurry is crucial. Since nitrogen is senescence over time from older tissues to newer ones to facilitate the growth of new cells [44], most fertilizers provide nitrogen as a supplement. Total Kjeldahl Nitrogen (TKN), Total Ammoniacal Nitrogen (TAN), and nitrogen as free nitrates were analyzed in all three samples at different retention periods as summarized in Table 6.

The general trend in all three nitrogen forms analyzed was a linear increase in concentration over the retention period. Hydrolysis of the kitchen waste biomass led to degradation of proteins present freeing more nitrogen as either elemental nitrogen, ammoniacal nitrogen, or anionic nitrates. Chen et al. [49] portrayed bioslurry nitrogen to be 2- to 2.7-fold higher than that in mineral fertilizer. The use of the two additives caused more degradation of the proteins and, therefore, these samples had more nitrogen content than their corresponding control sample. The total Kjeldahl nitrogen and free nitrate content on the 28 th day of retention time values belonged to the same population (95\% confidence level, $n=14)$. However, the total ammoniacal nitrogen level of the control sample $(10.803 \pm 0.652 \mathrm{~g} / \mathrm{L})$ did not fit into the population of the samples with additives, i.e., T. brownii $(14.599 \pm 0.425 \mathrm{~g} / \mathrm{L})$ and Acanthaceae spp. $(15.767 \pm 1.243 \mathrm{~g} / \mathrm{L})(\alpha=0.05, n=14)$. Biogas slurry ammonium levels are known to increase linearly over time [50]. It is worth noting that the Acanthaceae spp. sample had the highest nitrogen content values during most periods of the retention time, and thus the best bioslurry as far as nitrogen is concerned. Figure 3 illustrates the UV-VIS spectra of nitrate levels for the three samples on retention day 28 .

6.7. Bioslurry Sulfur Content. Like nitrogen, sulfur is an essential nutrient and thus a major plant requirement [51]. Kitchen waste is prone to a combination of several proteins and elucidation of sulfur content as a bioslurry component is necessary. The bioslurry from the three samples was analyzed for total sulfur (TS) and free sulfate content at various retention periods as summarized in Table 7 . 
TABLE 6: Variation of total Kjeldahl nitrogen (TKN), total ammoniacal nitrogen (TAN), and nitrogen as free nitrates in bioslurry over the retention period.

\begin{tabular}{|c|c|c|c|c|c|c|}
\hline \multirow{2}{*}{ Samples } & \multirow{2}{*}{ Parameter } & \multicolumn{5}{|c|}{ Sample days } \\
\hline & & Day 1 & Day 7 & Day 14 & Day 21 & Day 28 \\
\hline \multirow{3}{*}{ Control } & TKN (g/L) & $1.850 \pm 0.700$ & $6.183 \pm 0.545$ & $11.083 \pm 0.867$ & $11.433 \pm 0.910$ & $12.367 \pm 0.652$ \\
\hline & TAN $(g / L)$ & $6.716 \pm 0.341$ & $6.816 \pm 0.420$ & $8.467 \pm 0.625$ & $9.635 \pm 0.888$ & $10.803 \pm 0.652$ \\
\hline & Free $\mathrm{NO}_{3}^{-}(\mathrm{ppm})$ & $420.810 \pm 0.00$ & $421.300 \pm 0.00$ & $423.010 \pm 0.000$ & $423.070 \pm 0.000$ & $424.010 \pm 0.000$ \\
\hline \multirow{3}{*}{ T. brownii } & TKN $(g / L)$ & $1.633 \pm 0.313$ & $9.100 \pm 0.632$ & $13.533 \pm 0.667$ & $13.767 \pm 0.882$ & $14.350 \pm 0.350$ \\
\hline & TAN $(\mathrm{g} / \mathrm{L})$ & $6.716 \pm 0.341$ & $10.511 \pm 0.000$ & $11.971 \pm 0.212$ & $12.847 \pm 0.885$ & $14.599 \pm 0.425$ \\
\hline & Free $\mathrm{NO}_{3}^{-}(\mathrm{ppm})$ & $421.360 \pm 0.00$ & $422.460 \pm 0.000$ & $424.010 \pm 0.000$ & $425.610 \pm 0.000$ & $425.770 \pm 0.000$ \\
\hline \multirow{3}{*}{ Acanthaceae spp. } & TKN $(\mathrm{g} / \mathrm{L})$ & $1.633 \pm 0.313$ & $7.000 \pm 0.583$ & $11.433 \pm 1.022$ & $12.367 \pm 0.652$ & $13.183 \pm 0.435$ \\
\hline & TAN $(\mathrm{g} / \mathrm{L})$ & $7.884 \pm 0.611$ & $10.803 \pm 0.552$ & $11.971 \pm 0.756$ & $13.431 \pm 0.857$ & $15.767 \pm 1.243$ \\
\hline & Free $\mathrm{NO}_{3}^{-}(\mathrm{ppm})$ & $420.690 \pm 0.00$ & $422.410 \pm 0.000$ & $424.170 \pm 0.000$ & $425.880 \pm 0.000$ & $427.870 \pm 0.000$ \\
\hline
\end{tabular}

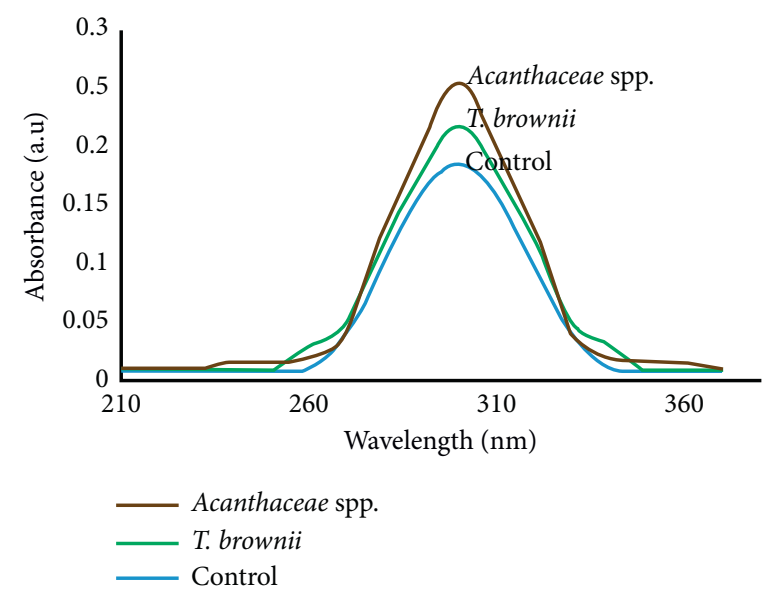

Figure 3: Nitrate levels in bioslurry after retention day 28.

TABLE 7: Variation in total sulfur and free sulfate levels over the retention period.

\begin{tabular}{|c|c|c|c|c|c|c|}
\hline \multirow{2}{*}{ Samples } & \multirow{2}{*}{ Parameter } & \multicolumn{5}{|c|}{ Sample days } \\
\hline & & Day 1 & Day 7 & Day 14 & Day 21 & Day 28 \\
\hline \multirow{2}{*}{ Control } & TS $(\mathrm{g} / \mathrm{L})$ & $2.178 \pm 0.315$ & $2.435 \pm 0.331$ & $2.950 \pm 0.000$ & $3.293 \pm 0.000$ & $4.842 \pm 0.005$ \\
\hline & Free $\mathrm{SO}^{2-}{ }_{4}(\mathrm{ppm})$ & $510.500 \pm 0.000$ & $535.710 \pm 0.000$ & $547.160 \pm 0.000$ & $568.930 \pm 0.000$ & $603.300 \pm 0.000$ \\
\hline \multirow[b]{2}{*}{ T. brownii } & TS $(\mathrm{g} / \mathrm{L})$ & $3.463 \pm 0.051$ & $1.853 \pm 0.023$ & $4.139 \pm 0.212$ & $5.381 \pm 0.022$ & $6.412 \pm 0.150$ \\
\hline & Free $\mathrm{SO}^{2-}{ }_{4}(\mathrm{ppm})$ & $533.420 \pm 0.000$ & $542.580 \pm 0.000$ & $634.230 \pm 0.000$ & $707.550 \pm 0.000$ & $829.505 \pm 0.000$ \\
\hline Acanthaceae spp. & $\begin{array}{c}\mathrm{TS}(\mathrm{g} / \mathrm{L}) \\
\text { Free } \mathrm{SO}^{2-}{ }_{4}(\mathrm{ppm})\end{array}$ & $\begin{array}{c}1.852 \pm 0.110 \\
536.850 \pm 0.000\end{array}$ & $\begin{array}{c}2.371 \pm 0.012 \\
568.930 \pm 0.000\end{array}$ & $\begin{array}{c}3.990 \pm 0.0120 \\
643.390 \pm 0.000\end{array}$ & $\begin{array}{c}4.921 \pm 0.121 \\
765.970 \pm 0.000\end{array}$ & $\begin{array}{c}5.612 \pm 0.151 \\
965.890 \pm 0.000\end{array}$ \\
\hline
\end{tabular}

Both total sulfur and free sulfate concentrations increased linearly during the retention period. The concentration of these compounds in the control sample was quite low compared to the samples with additives. While total sulfur concentration after day 28 of the retention period $(4.842 \pm 0.005) \mathrm{g} / \mathrm{L}$ belonged to the same population with the samples with additives, the free sulfate concentration of this sample was significantly different at a $95 \%$ confidence level $(n=14)$. The levels of sulfate after 28 days of retention period are illustrated by the UV-VIS Spectra in Figure 4.

6.8. Bioslurry Phosphorus Content. Together with nitrogen and potassium, phosphorus is one of the three basic fertilizer requirements $[41,51]$. Phosphorus is abundant in kitchen waste biomass due to the presence of the various proteins present [52]. The levels of various forms of phosphorus which are total phosphorus (TP), total phosphoric acid (TPA), and phosphorus as free phosphates in the three bioslurry samples were analyzed over the retention period as summarized in Table 8.

The concentrations of all three phosphorus analytes in all samples increased linearly over the retention period. The total phosphorus content in the control sample $(1.960 \pm 0.088 \mathrm{~g} / \mathrm{L})$ was proven to be an outlier at a $95 \%$ confidence level when compared to that of $T$. brownii $(2.520 \pm 0.250 \mathrm{~g} / \mathrm{L})$ and Acanthaceae spp. $(2.420 \pm 0.648 \mathrm{~g} / \mathrm{L})$ sample $(n=14)$. The levels of total phosphoric acid in the T. brownii sample $(3.477 \pm 0.023 \mathrm{~g} / \mathrm{L})$ were much higher compared to the rest and also significantly different 


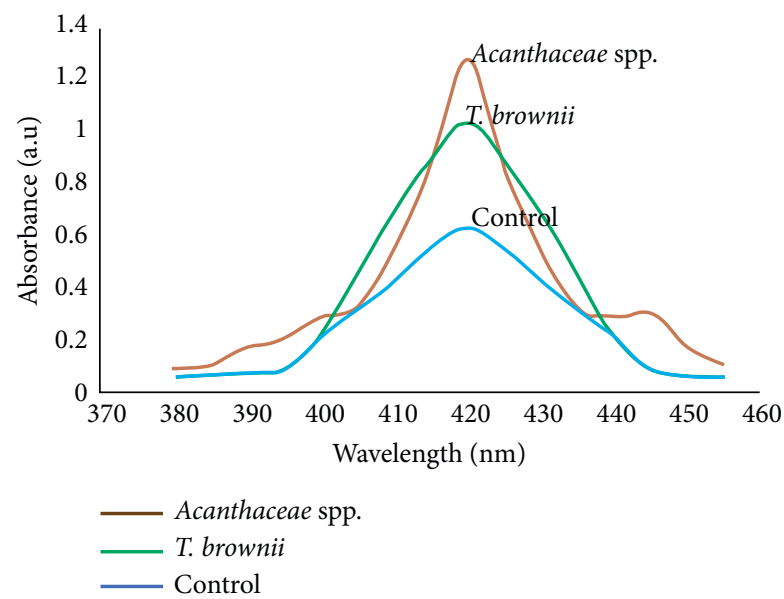

Figure 4: Bioslurry sulfate levels after retention day 28.

TABLE 8: Variation of total phosphorus, total phosphoric acid, and free phosphates in bioslurry over the retention period.

\begin{tabular}{|c|c|c|c|c|c|c|}
\hline \multirow{2}{*}{ Samples } & \multirow{2}{*}{ Parameter } & \multicolumn{5}{|c|}{ Sample days } \\
\hline & & Day 1 & Day 7 & Day 14 & Day 21 & Day 28 \\
\hline \multirow{3}{*}{ Control } & $\mathrm{TP}(\mathrm{g} / \mathrm{L})$ & $0.780 \pm 0.020$ & $1.335 \pm 0.025$ & $1.560 \pm 0.019$ & $2.305 \pm 0.062$ & $1.960 \pm 0.088$ \\
\hline & TPA $(\mathrm{g} / \mathrm{L})$ & $2.399 \pm 0.112$ & $2.745 \pm 0.002$ & $2.835 \pm 0.563$ & $2.925 \pm 0.156$ & $2.963 \pm 0.333$ \\
\hline & Free $\mathrm{PO}^{3-}{ }_{4}(\mathrm{ppm})$ & $465.350 \pm 0.000$ & $466.000 \pm 0.000$ & $468.520 \pm 0.000$ & $475.940 \pm 0.000$ & $477.430 \pm 0.000$ \\
\hline \multirow{3}{*}{ T. brownii } & $\mathrm{TP}(\mathrm{g} / \mathrm{L})$ & $0.587 \pm 0.023$ & $1.232 \pm 0.055$ & $2.420 \pm 0.648$ & $2.490 \pm 0.171$ & $2.520 \pm 0.250$ \\
\hline & TPA $(\mathrm{g} / \mathrm{L})$ & $2.822 \pm 0.346$ & $3.040 \pm 0.422$ & $3.040 \pm 0.000$ & $3.389 \pm 0.001$ & $3.477 \pm 0.023$ \\
\hline & Free $\mathrm{PO}^{3-}{ }_{4}(\mathrm{ppm})$ & $465.350 \pm 0.000$ & $467.730 \pm 0.000$ & $468.520 \pm 0.00$ & $476.240 \pm 0.000$ & $477.630 \pm 0.000$ \\
\hline \multirow{3}{*}{ Acanthaceae spp. } & $\mathrm{TP}(\mathrm{g} / \mathrm{L})$ & $0.660 \pm 0.000$ & $1.345 \pm 0.076$ & $1.525 \pm 0.454$ & $1.675 \pm 0.112$ & $2.420 \pm 0.648$ \\
\hline & TPA $(\mathrm{g} / \mathrm{L})$ & $2.567 \pm 0.316$ & $2.655 \pm 0.814$ & $2.694 \pm 0.000$ & $2.771 \pm 0.169$ & $2.771 \pm 0.231$ \\
\hline & Free $\mathrm{PO}^{3-}{ }_{4}(\mathrm{ppm})$ & $465.400 \pm 0.000$ & $470.990 \pm 0.000$ & $477.430 \pm 0.000$ & $480.940 \pm 0.000$ & $486.140 \pm 0.000$ \\
\hline
\end{tabular}

$(\alpha=0.05, n=14)$. The levels of phosphate after 28 days of retention period belonged to the same population. These levels are illustrated by UV-VIS Spectra in Figure 5;

The phosphate levels after retention day 28 were similar to those of bioslurry attained using pure animal manure, i.e., $488 \mathrm{mg} / \mathrm{kg}$ [48].

6.9. Bioslurry Soluble Silicic Acid. Soluble silicic acid (orthosilicic acid) is a micronutrient which is very important in the growth and yields of most grasses (including maize, rice, and wheat) $[53,54]$. Soluble silicic acid is usually sprayed as a foliar [55]. The levels of soluble silicic acid in the control and Acanthaceae spp. samples fluctuated throughout the retention period. Optimal soluble silicic acid levels were obtained after 21 days of the retention period for the control sample $(31.667 \pm 0.000 \mathrm{mg} / \mathrm{L})$ and after 14 retention days for the sample with Acanthaceae spp. extract $(32.778 \pm 1.543 \mathrm{mg} / \mathrm{L})$. Soluble silicic acid levels in the T. brownii sample increased linearly over the retention period. This is attributed to the continuous mineralization of silica in the biogas slurry over time. Gorrepati et al. [56] proved that the availability of silica in a solution is related to its $\mathrm{pH}$ value. Under acidic conditions, silica precipitates out by first polymerizing and then flocculating. The availability of silica for plant uptake is, therefore, reduced. Therefore, there was a drop in the soluble silicic acid values between day

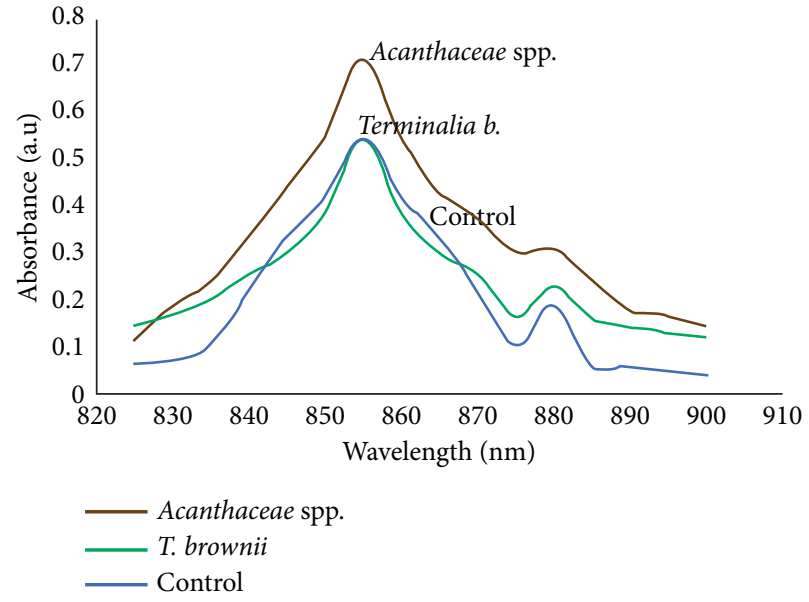

FIGURE 5: Phosphate levels in bioslurry after retention day 28.

21 and day 28 due to the decrease in $\mathrm{pH}$ of the biogas slurry. The levels after retention day 28 in the T. brownii sample $(38.334 \pm 2.492 \mathrm{mg} / \mathrm{L})$ were proven to be significantly different from those of the control sample $(25.001 \pm 0.000 \mathrm{mg} / \mathrm{L})$ and Acanthaceae spp. (20.556 \pm $0.533 \mathrm{mg} / \mathrm{L})(\alpha=0.05, n=14)$. Table 9 illustrates the trends in soluble silicic acid content in the three samples over the retention period. 
Table 9: Variation of soluble silicic acid with time in the bioslurry samples.

\begin{tabular}{lccccc}
\hline Samples & & \multicolumn{3}{c}{ Soluble silicic acid (mg/L) } \\
& Day 1 & Day 7 & Day 14 & Day 21 & Day 28 \\
\hline Control & $27.778 \pm 0.125$ & $26.667 \pm 0.145$ & $30.001 \pm 0.000$ & $31.667 \pm 0.000$ & $25.001 \pm 0.000$ \\
T. brownii & $23.889 \pm 0.463$ & $26.667 \pm 0.145$ & $31.112 \pm 2.357$ & $41.112 \pm 1.253$ & $38.334 \pm 2.492$ \\
Acanthaceae spp. & $25.475 \pm 0.357$ & $28.889 \pm 3.142$ & $32.778 \pm 1.543$ & $30.001 \pm 0.000$ & $20.556 \pm 0.533$ \\
\hline
\end{tabular}

Soluble silicic acid is vital in reinforcing plant cell walls, increasing tolerance to drought and heavy metals, pests, and diseases [57].

\section{Conclusions}

Whereas T. brownii additives were found to be highly conjugated, Acanthaceae spp. additives had more biometal concentrations. These factors helped in the degradation of the biogas substrate for the formation of more available nutrients. The samples with these two additives were found to have more available nutrients compared to the control sample in all parameters tested. The levels of the plant nutrients analyzed were found to increase over time with retention day 28 having the highest values. The samples with additives had more plant available nutrients compared to the control. T. brownii sample had more total Kjeldahl nitrogen, total ammoniacal nitrogen, total sulfur, total phosphorus, total phosphoric acid, and appreciably higher soluble silicic acid values compared to the rest. On the other hand, the Acanthaceae spp. sample had the highest potassium, calcium, nitrates, sulfates, and free phosphates levels compared to the other samples.

The use of T. brownii and Acanthaceae spp. additives was thus proven to increase the available plant nutrients in bioslurry.

\section{Abbreviations}

FT-IR: $\quad$ Fourier transform infrared

UV-VIS: Ultraviolet visible

VOS/TAC: Volatile organic salts/total anorganic carbon

EC: $\quad$ Electrical conductivity

LOI: Loss on ignition

OC: $\quad$ Organic carbon

TAN: $\quad$ Total ammoniacal nitrogen

TKN: Total Kjeldahl nitrogen

TP: $\quad$ Total phosphorus

TPA: Total phosphoric acid

TS: $\quad$ Total sulfur.

\section{Data Availability}

The data used to support the findings of this study are included within the article.

\section{Conflicts of Interest}

The authors declare that there are no conflicts of interest regarding the publication of this paper.

\section{Acknowledgments}

The researchers wish to express their sincere gratitude to Maasai Mara, Taita Taveta, and Vaal Universities for the provision of lab facilities used during characterization and analysis of the additives and the bioslurry. Mr. Koti Musumba, Mr. Patrick Lumumba, Mr. Kenneth Rutto, and Md Linda Mesoppirr were also quite instrumental in the analysis of the samples. The authors would like to appreciate the Centre for Innovation, New and Renewable Energy (CINRE) department of Maasai Mara University for providing space where the biodigesters were monitored.

\section{References}

[1] R. Lal, "Digging deeper: a holistic perspective of factors affecting soil organic carbon sequestration in agroecosystems," Global Change Biology, vol. 24, no. 8, pp. 3285-3301, 2018.

[2] R. Fujinuma, G. Kirchhof, A. Ramakrishna et al., "Intensified sweetpotato production in Papua New Guinea drives plant nutrient decline over the last decade, Agriculture," Ecosystems and Environment, vol. 254, pp. 10-19, 2018.

[3] P. Bindraban, C. Dimkpa, L. Nagarajan, A. Roy, and R. Rabbinge, "Revisiting fertilisers and fertilisation strategies for improved nutrient uptake by plants," Biology and Fertility of Soils: Cooperating Journal of International Society of Soil Science, vol. 51, no. 8, pp. 897-911, 2015.

[4] D. K. A. Al-Taey, J. C. Imad, and B. H. K. AL-Naely, "A study on effects of water quality, cultivars, organic and chemical fertilizers on potato (Solanum tuberosum L.) growth and yield to calculate the economic feasibility," Bulgarian Journal of Agricultural Science, vol. 25, no. 6, pp. 1239-1245, 2019.

[5] G. Rahmann, A. Reza, P. Bàrberi et al., "Organic agriculture 3.0 is innovation with research," Organic Agriculture: Official Journal of the International Society of Organic Agriculture Research, vol. 7, no. 3, pp. 169-197, 2017.

[6] L. Terry and R. Summers, "Biodegradable organic matter and rapid-rate biofilter performance: a review," Water Research, vol. 128, pp. 234-245, 2018.

[7] V. Vásquez and L. De, "Environment air pollution related to ART facilities and its potential involvement in IVF outcomes," Medicina Reproductiva y Embriología Clinica, vol. 6, no. 1, pp. 15-32, 2019.

[8] M. Bengtsson, K. Attermeyer, and N. Catalán, "Interactive effects on organic matter processing from soils to the ocean: are priming effects relevant in aquatic ecosystems," Hydrobiologia: The International Journal of Aquatic Sciences, vol. 822, no. 1, pp. 1-17, 2018.

[9] G. Re, G. Piluzza, F. Sanna, M. Molinu, and L. Sulas, "Polyphenolic composition and antioxidant capacity of legume-based swards are affected by light intensity in a Mediterranean agroforestry system," Journal of the Science of Food and Agriculture, vol. 99, no. 1, pp. 191-198, 2019. 
[10] C. Hruby, M. Soupir, T. Moorman, C. Pederson, and R. Kanwar, "Salmonella and fecal indicator bacteria survival in soils amended with poultry manure," Water, Air, \& Soil Pollution, vol. 229, no. 2, p. 32, 2018.

[11] C. Yan, L. Zhang, X. Luo, and Z. Zheng, "Influence of influent methane concentration on biogas upgrading and biogas slurry purification under various LED (light-emitting diode) light wavelengths using Chlorella sp." Energy, vol. 69, pp. 419-426, 2014.

[12] S. Mohamed, "Experience gained in the research-to-development continuum," Mountain Research and Development, vol. 21, no. 2, pp. 118-122, 2001.

[13] Y. Chen, K. Xiao, X. Jiang, N. Shen, R. Zeng, and Y. Zhou, "Long solid retention time (SRT) has minor role in promoting methane production in a $65^{\circ} \mathrm{C}$ single-stage anaerobic sludge digester," Bioresource Technology, vol. 247, pp. 724-729, 2018.

[14] O. A. Mosima, O. E. Rangondi, O. Nathan, and K. Jackson, "Compositional and structural characterization of indigenous salts in Kenya: a case study of "para," "magadi" and "lebek" crystalline salts," International Journal of BioChemiPhysics, vol. 20, pp. 56-61, 2012.

[15] A. O. Mosima, O. E. Rangondi, O. Nathan, and K. Jackson, “A study of the heterogeneous dilute indigenous carbonate salt hydrolysis of the non-woody ligno-cellulosic plant samples," International Journal of Scientific \& Engineering Research, vol. 4, no. 6, p. 333, 2015.

[16] J. Kjeldahl, "New method for the determination of nitrogen in organic substances," Zeitschrift für Analytische Chemie, vol. 22, no. 1, pp. 366-383, 1883.

[17] FAO, "Standard operating procedure for soil organic carbon Walkley-Black method titration and colorimetric method," 2020, http://www.fao.org/3/ca7471en/CA7471EN.pdf.

[18] I. Kabir, H. Taushik, A. Amin et al., Portable UV-Spectrophotometer to Determine the Concentration of Potassium, BRAC University, Dhaka, Bangladesh, 2017.

[19] K. Masayoshi, Second Revision of the Methods of Analysis of Fertilizers (Details), Yokendo, Tokyo, Japan, 1988.

[20] S. Abe, S. Chika, and S. Yuji, "Testing method of the total amount of sulfur content (as sulfur trioxide): a collaborative study,", Research Report of Fertilizer, vol. 7, pp. 28-35, 2014.

[21] K. Kimie, C. Masaki, and W. Erina, "Verification of performance characteristics of testing method for ammonia nitrogen content in fertilizer by formaldehyde method," Research Report of Fertilizer, vol. 6, pp. 139-147, 2013.

[22] S. Yasushi, "Validation of gravimetric analysis for determination of sulfur content (as sulfur trioxide) in sulfur and its compounds as fertilizers," Research Report of Fertilizer, vol. 4, pp. 9-15, 2011.

[23] A. Bartyzel, "Synthesis, thermal study and some properties of $\mathrm{N}_{2} \mathrm{O}_{4}$-donor Schiff base and its $\mathrm{Mn}(\mathrm{III}), \mathrm{Co}(\mathrm{II}), \mathrm{Ni}(\mathrm{II})$, $\mathrm{Cu}(\mathrm{II})$ and $\mathrm{Zn}(\mathrm{II})$ complexes," Journal of Thermal Analysis and Calorimetry: An International Forum for Thermal Studies, vol. 127, no. 3, pp. 2133-2147, 2017.

[24] L. Breydo and V. Uversky, "Structural, morphological, and functional diversity of amyloid oligomers," FEBS Letters, vol. 589, pp. 2640-2648, 2015.

[25] T. Pilipczuk, N. Dawidowska, B. Kusznierewicz, J. Namieśnik, and A. Bartoszek, "Simultaneous determination of indolic compounds in plant extracts by solid-phase extraction and high-performance liquid chromatography with UV and fluorescence detection," Food Analytical Methods, vol. 8, no. 9, pp. 2169-2177, 2015.

[26] L. Bertini, M. Alberto, F. Arrigoni et al., "On the photochemistry of $\mathrm{Fe}_{2}(\mathrm{edt})(\mathrm{CO})_{4}\left(\mathrm{PMe}_{3}\right)_{2}$, a $[\mathrm{Fe}-\mathrm{Fe}]$-hydrogenase model: a DFT/TDDFT investigation," International Journal of Quantum Chemistry, vol. 118, Article ID e25537, 2018.

[27] L. Xu, F. Guo, G. Wang et al., "Correlations between slow pyrolysis characteristics and organic carbon structure of aquatic plant biomass," Environmental Science and Pollution Research, vol. 26, no. 17, pp. 17555-17566, 2019.

[28] V. Obuseng and M. Moshoeshoe, "Simultaneous determination of nitrate, nitrite and phosphate in environmental samples by high performance liquid chromatography with UV detection," South African Journal of Chemistry, vol. 71, no. 1, pp. 79-85, 2018.

[29] D. Şöhretoğlu, M. Baran, R. Arroo, and A. Kuruüzüm-Uz, "Recent advances in chemistry, therapeutic properties and sources of polydatin," Phytochemistry Reviews: Fundamentals and Perspectives of Natural Products Research, vol. 17, no. 5, pp. 973-1005, 2018.

[30] K. Zhang, L. Chen, Y. Li, P. Brookes, J. Xu, and Y. Luo, “The effects of combinations of biochar, lime, and organic fertilizer on nitrification and nitrifiers," Biology and Fertility of Soil: Cooperating Journal of International Society of Soil Science, vol. 53, no. 1, pp. 77-87, 2017.

[31] A. Osano, L. Cheruiyot, J. Chacha, and J. Maghanga, "Role of organic nutrients on the distribution of macro-invertebrates; a case study of river Sosiani, Eldoret town," Journal of Agriculture, Pure and Applied Science and Technology, vol. 4, pp. 32-39, 2009.

[32] S. Barga, T. Dilts, and E. Leger, "Climate variability affects the germination strategies exhibited by arid land plants," Oecologia, vol. 185, no. 3, pp. 437-452, 2017.

[33] G. Wamelink, D. Walvoort, M. Sanders et al., "Prediction of soil $\mathrm{pH}$ patterns in nature areas on a national scale," Applied Vegetation Science, vol. 22, no. 2, pp. 189-199, 2019.

[34] K. Kucharska, I. Hołowacz, D. Konopacka-Łyskawa, P. Rybarczyk, and M. Kamiński, "Key issues in modeling and optimization of lignocellulosic biomass fermentative conversion to gaseous biofuels," Renewable Energy: Part A, vol. 129, pp. 384-408, 2018.

[35] E. Vasconcelos, R. Leitão, and S. Santaella, "Factors that affect bacterial ecology in hydrogen-producing anaerobic reactors," Bioenergy Research, vol. 9, no. 4, pp. 1260-1271, 2016.

[36] P. Chaterjee, S. Neogi, S. Saha, B. Jeon, and A. Dey, "Low pH treatment of starch industry effluent with bacteria from leaf debris for methane production," Water Environment Research, vol. 91, no. 5, pp. 377-385, 2019.

[37] F. Sabbadin, G. Pesante, L. Elias et al., "Uncovering the molecular mechanisms of lignocellulose digestion in shipworms," Biotechnology for Biofuels, vol. 11, 2018.

[38] S. Türtscher, P. Berger, L. Lindebner, and T. W. Berger, "Declining atmospheric deposition of heavy metals over the last three decades is reflected in soil and foliage of 97 beech (Fagus sylvatica) stands in the Vienna woods," Environmental Pollution, vol. 230, pp. 561-573, 2017.

[39] S. Behera and A. Shukla, "Spatial distribution of surface soil acidity, electrical conductivity, soil organic carbon content and exchangeable potassium, calcium and magnesium in some cropped acid soils of India," Land Degradation \& Development, vol. 26, no. 1, pp. 71-79, 2015.

[40] W. Zhang, L. Wu, X. Wu et al., "Lodging resistance of japonica rice (Oryza sativa L.): morphological and anatomical traits due to top-dressing nitrogen application rates," Rice, vol. 9, no. 1, pp. 1-11, 2016.

[41] P. Kisinyo, J. Maghanga, C. Othieno et al., "Phosphorus sorption and lime requirements of maize growing acid soils of 
Kenya," Sustainable Agriculture Research, vol. 2, no. 2, pp. 1-123, 2013.

[42] V. Balderas-Hernández, K. Correia, and R. Mahadevan, "Inactivation of the transcription factor mig1 (YGL035C) in Saccharomyces cerevisiae improves tolerance towards monocarboxylic weak acids: acetic, formic and levulinic acid," Journal of Industrial Microbiology \& Biotechnology, vol. 45, no. 8, pp. 735-751, 2018.

[43] M. Vestergård Madsen, T. Bang-Andreasen, S. M. Buss et al., "The relative importance of the bacterial pathway and soil inorganic nitrogen increase across an extreme wood-ash application gradient," GCB Bioenergy, vol. 10, no. 5, pp. $320-334,2018$.

[44] B. Chaka and A. Osano, "Analysis of selected nutrient levels at different growth stages of Dovyalis caffra (kei-apple fruits)," International Journal of Research and Innovation in Applied Sciences, vol. 4, no. 5, pp. 11-18, 2019.

[45] N. Akhtar, K. Gupta, D. Goyal, and A. Goyal, "Recent advances in pretreatment technologies for efficient hydrolysis of lignocellulosic biomass," Environmental Progress \& Sustainable Energy, vol. 35, no. 2, pp. 489-511, 2016.

[46] M. Ošlaj, S. Kraner, M. Lakota, and P. Vindišs "Parametric and nonparametric approaches for detecting the most important factors in biogas production," Polish Journal of Environmental Studies, vol. 28, no. 1, pp. 291-301, 2019.

[47] L. Wang, S. Guo, Y. Wang, D. Yi, and J. Wang, "Poultry biogas slurry can partially substitute for mineral fertilizers in hydroponic lettuce production," Environmental Science and Pollution Research, vol. 26, no. 1, pp. 659-671, 2019.

[48] K. Kuligowski, T. Poulsen, G. Rubæk, and P. Sørensen, "Plantavailability to barley of phosphorus in ash from thermally treated animal manure in comparison to other manure-based materials and commercial fertilizer," European Journal of Agronomy, vol. 33, no. 4, pp. 293-303, 2010.

[49] G. Chen, G. Zhao, H. Zhang et al., "Biogas slurry use as N fertilizer for two-season Zizania aquatica Turcz. in China," Nutrient Cycling in Agroecosystems, vol. 107, no. 3, pp. 303320, 2017.

[50] M. Garćia-Sánchez, I. García-Romera, J. Száková, L. Kaplan, and P. Tlustoš, "The effectiveness of various treatments in changing the nutrient status and bioavailability of risk elements in multi-element contaminated soil," Environmental Science and Pollution Research, vol. 22, no. 18, pp. 1432514336, 2015.

[51] L. Augusto, D. Achat, M. Jonard, D. Vidal, and B. Ringeval, "Soil parent material-a major driver of plant nutrient limitations in terrestrial ecosystems," Global Change Biology, vol. 23, no. 9, pp. 3808-3824, 2017.

[52] C. Azevedo, A. Cheavegatti-Gianotto, B. Negri et al., "Multiple interval QTL mapping and searching for PSTOL1 homologs associated with root morphology, biomass accumulation and phosphorus content in maize seedlings under low-P," BMC Plant Biology, vol. 15, p. 172, 2015.

[53] Z. Li, D. Unzué-Belmonte, J. Cornelis et al., "Effects of phytolithic rice-straw biochar, soil buffering capacity and $\mathrm{pH}$ on silicon bioavailability," Plant and Soil: An International Journal on Plant-Soil Relationships, vol. 438, pp. 187-203, 2019.

[54] F. Hosseini, M. Mosaddeghi, A. Dexter, and M. Sepehri, "Maize water status and physiological traits as affected by root endophytic fungus Piriformospora indica under combined drought and mechanical stresses," Planta: An International Journal of Plant Biology, vol. 247, no. 5, pp. 1229-1245, 2018.
[55] A. Nascimento, F. Assis, J. Moraes, and B. Souza, "Silicon application promotes rice growth and negatively affects development of Spodoptera frugiperda (J. E. Smith)," Journal of Applied Entomology, vol. 142, pp. 241-249, 2018.

[56] E. Gorrepati, P. Wongthahan, S. Raha, and H. Fogler, "Silica precipitation in acidic solutions: mechanism, ph effect, and salt effect," Langmuir, vol. 26, pp. 10467-10474, 2010.

[57] M. Luyckx, J.-F. Hausman, S. Lutts, and G. Guerriero, "Silicon and plants: current knowledge and technological perspectives," Frontiers in Plant Science, vol. 8, p. 411, 2017. 